\title{
Failure of Foliar-Applied Biostimulants to Enhance Drought and Salt Tolerance in Urban Trees
}

\author{
Jonathan M. Banks and Glynn C. Percival
}

\begin{abstract}
Urban environments present an array of environmental conditions detrimental to the biology of trees. Two major problems include deicing salts, a common soil pollutant, and drought. One potential option for managing these environmental disorders may be through the application of commercially available biostimulants, as these products are reported to enhance a plant's resistance to environmental stresses. Trials used containerized stock of evergreen oak (Quercus ilex), holly (Ilex aquifolium), rowan (Sorbus aucuparia), and beech (Fagus sylvatica) to evaluate the effectiveness of seven commercially available biostimulants as drought and salt protectant compounds. Results conclude that none of the biostimulants evaluated in this study provided any significant degree of salt or drought damage protection compared to water-treated controls.

Key Words. Drought Tolerance; Environmental Stress; Fagus sylvatica; Ilex aquifolium; Landscape Disorders; Plant Health Care; Quercus ilex; Salt Tolerance; Sorbus aucuparia; Tree Physiology.
\end{abstract}

With increased global average temperature and extremes in global weather patterns recorded (Pachauri and Reisinger 2007), those involved in managing urban trees are dealing with an ever increasing number of weather-related tree disorders, such as drought and subzero temperatures resulting in the application of deicing salts (Gibbs and Palmer 1994; Black 2012). Drought- and salt-related injuries appear as leaf yellowing, tip and/or peripheral leaf burn, stunted growth, defoliation, and potentially tree death (Cresswell and Weir 1997; Roberts et al. 2006). Salt damage to plants is often associated with deicing salt applications to roads and pavements (sidewalks) that manifests itself in two forms. One mechanism reduces water availability to plant roots through reduced soil osmotic potential (i.e., water flows from the root system back into the soil), while the other directly damages aboveground plant parts, causing direct toxicity burn symptoms. Drought stress is also of interest because it is regarded as one of the major abiotic stress factors (Akıncı and Lösel 2012). Drought resistance also displays crossresistance (i.e., "resistance to one stress, induced by acclimation to another") (Taiz and Zeiger 1991, p. 347); therefore, it could be considered that a substance found to counter drought stress could prove to influence other plant stresses, thus proving useful in the search for holistic solutions to tree care.

Control measures for environmental disorders generally involve modifying the external growing environment, including, for example, mulching to reduce evaporative soil water losses caused by high temperatures and to prevent percolation of deicing salts into the soil (ChalkerScott 2007; Percival et al. 2009). Alternatively, modifying a plant's internal chemical environment has shown promise. One example of this is the concept of sucrose-induced tolerance to salt damage (Al-Habsi and Percival 2006). Biostimulants differ from traditional nitrogen, phosphorous, and potassium fertilizers in that their active ingredient consists of a range of organic compounds, such as plant hormones, humic acids, marine algae extracts, sea kelp, vitamins, and other chemicals that vary according to the manufacturer (Ferrini and Nicese 2002). Biostimulants, it is claimed, influence plant metabolism and subsequently enhanced plant stress toler- 
ance. For example, substances such as calcium, often an ingredient of biostimulants, are known to influence changes in cell integrity (Glenn et al. 1988; Marschner 2012) thought to reduce physical damages such as freeze-thaw injury and the osmotic stresses caused by drought and salt damage (Raese 1996; Percival and Barnes 2008). Others promote an increase in overall plant vitality on the premise that a healthy plant is more likely to resist infection than an unhealthy plant (Marçais and Bréda 2006). Other studies have shown that biostimulants in the form of marine algae extracts significantly mitigate drought stress (Mancuso et al. 2006; Spann and Little 2010).

This study was undertaken to determine the effectiveness of a range of different biostimulants-shown in Table 1to enhance both drought and salt tolerance.

\section{MATERIALS AND METHODS}

Four-year-old containerized trees were sprayed until runoff using a handheld sprayer with seven commercially available biostimulants (Table 1), applied i) at manufacturers' recommended rates and ii) double the recommended concentration. Randomized block designs assigned the position of the trees and eight trees per treatment were used.

Biostimulant enhancement of drought tolerance commenced on day 10 after applying each biostimulant. Five leaves per tree, ten trees per treatment of evergreen oak (Quercus ilex), rowan (Sorbus aucuparia), and beech (Fagus sylvatica) were detached. Immediately following detachment, leaves were dehydrated under labora- tory conditions by placing abaxial surface down in an uncovered Petri dish, on Whatmans filter paper, and placed in a Merck Environmental Growth Chamber at $21^{\circ} \mathrm{C}$ for 24 hours at a $35 \%$ relative humidity and low light intensity of 15 $\mu \mathrm{mol} \mathrm{m} \mathrm{m}^{-2} \mathrm{~s}^{-1}$ Photosynthetically Active Radiation (PAR) to induce stomatal opening and facilitate maximal water loss from leaf tissue (Jensen et al. 1999; Percival and Sheriffs 2002).

Biostimulant enhancement of salt tolerance was assessed using holly (Ilex aquifolium) and evergreen oak. At day 10 after biostimulant application, five leaves per tree, 10 trees per biostimulant treatment were detached and subjected to sprays of $0 \%$ (control), 3\%, 6\%, 9\%, 12\% salt (sodium chloride, $\mathrm{NaCl}$ ) applied until runoff using a handheld sprayer to represent control $(0 \%)$, minimal (3\%), mild (6\%), standard (9\%), and severe $(12 \%)$ salt damage. Lethal salt concentrations $\left(\mathrm{SC}_{50}\right)$ were then calculated at the $50 \%$ level (i.e., the salt concentration required to reduce leaf chlorophyll fluorescence $\mathrm{Fv} / \mathrm{Fm}$ values as a measure of photosynthetic efficiency by $50 \%$ ).

\section{Chlorophyll Fluorescence}

Enhancement of drought and/or salinity tolerance was recorded by measurement of leaf chlorophyll fluorescence $\mathrm{Fv} / \mathrm{Fm}$ values. $\mathrm{Fv} / \mathrm{Fm}$ is considered a measure of leaf photochemical efficiency (Rosenqvist and van Kooten 2003) that in turn can be used as a non-destructive and rapid measure of plant vitality and early diagnostic of stress in plants (Meinander et al. 1996). This was achieved by recording values 72 hours post

Table 1. Selected biostimulants evaluated to enhance drought and salt tolerance.

\begin{tabular}{lll}
\hline Product & Active ingredient & Supplier \\
\hline Maxicrop Original & Seaweed extract & Maxicrop (UK) Ltd, P.O. Box 6027, Corby, UK \\
Resistim & Betaine & Mandops UK Ltd, Eastleigh, Hampshire, UK \\
Bioplex & $\begin{array}{l}\text { Seaweed + humic acid } \\
\text { extract }\end{array}$ & United Agri Products Ltd, Alconbury Weston, UK \\
Fulcrum CRV & Molasses & Banks Cargill Agriculture Ltd, St Hughs, Lincoln, UK \\
Redicrop & $\begin{array}{l}\text { Seaweed (cytokinin } \\
\text { activity) }\end{array}$ & United Agri Products Ltd, Alconbury Weston, UK \\
Crop Set & $\begin{array}{l}\text { Lactobacillus fermentation } \\
\text { product and B5 vitamins }\end{array}$ & United Agri Products Ltd, Alconbury Weston, UK \\
Superthrive & $\begin{array}{l}\text { Vitimin B and Auxin } \\
\text { (NAA) }\end{array}$ & Bartlett Tree Research Laboratory, Charlotte, NC, USA \\
\hline
\end{tabular}


salinity treatments and after 48 -hour dehydration. Leaves were adapted to darkness for 30 minutes by attaching light exclusion clips to the leaf surface and chlorophyll fluorescence was measured using a HandyPEA portable fluorescence spectrometer (Hansatech Instruments Ltd, King's Lynn, UK). Measurements were recorded up to 1 second with a data acquisition rate of $10 \mu \mathrm{s}$ for the first $2 \mathrm{~ms}$ and of $1 \mathrm{~ms}$ thereafter. The fluorescence responses were induced by a red (peak at $650 \mathrm{~nm}$ ) light of 1500 $\mu \mathrm{mol} \mathrm{m} \mathrm{m}^{-2} \mathrm{~s}^{-1}$ PAR intensity provided by an array of three light-emitting diodes. The ratio of variable $(\mathrm{Fv}=\mathrm{Fm}-\mathrm{Fo})$ to maximal (Fm) fluorescence (i.e., $\mathrm{Fv} / \mathrm{Fm}$, where $\mathrm{Fo}=$ minimal fluorescence) of darkadapted leaves were used to quantify the detrimental effects of freezing and salinity on leaf tissue.

\section{Statistical Methods}

Statistical analysis of drought tolerance was determined by GenStat release 13. Differences between treatment means were separated by the least significance difference (LSD) calculated at the $5 \%$ confidence level $(P<0.05)$. With respect to salt damage, chlorophyll fluorescence Fv/Fm values were plotted against the treatment salt concentration $(0 \%, 3 \%$, $6 \%, 9 \%$, and $12 \%$ ) and a classic logistic function was fitted to the viability data using SlideWrite software. The salt concentration causing 50\% leaf photosynthetic damage $\left(\mathrm{SC}_{50}\right)$ based on $\mathrm{Fv} / \mathrm{Fm}$ values was calculated for each tree as a parameter of the logistic function that was read from the curve fitting protocol. Each $\mathrm{SC}_{50}$ value per species was subjected to a one-way analysis of variance; when significant differences were found, means were compared using LSD at the 5\% confidence level. Levene's (1960) test was used to determine the homoscedasticity of variances in all cases. Standard deviation and coefficient of variation for data sets is also presented.

\section{RESULTS}

None of the biostimulants evaluated in this study, irrespective of concentration applied, provided any significant degree of salt or drought enhancement to any of the tree species used for experimental purposes. Chlorophyll fluorescence Fv/Fm values as a measure of drought and salt induced damage to the leaf photosynthetic system in biostimulant-treated trees were always statistically comparable with water-treated controls. Differences in the magnitude of foliar drought and salinity tolerance were observed between species. Foliar drought tolerance, as based on damage to the leaf photosynthetic system ( $\mathrm{Fv} / \mathrm{Fm}$ values) of control trees, indicated species tolerance in the order: evergreen oak > rowan $>$ beech (Table 2 ). Foliar salinity tolerance, as based on damage to the leaf photosynthetic system (Fv/Fm values) of control trees, indicated species tolerance in the order: evergreen oak > holly (Table 3 ).

Table 2. The influence of 48 hours dehydration on chlorophyll fluorescence (Fv/Fm) of detached leaves of woody plants.

\begin{tabular}{|c|c|c|c|c|}
\hline Treatment & $\begin{array}{l}\text { Concentration } \\
\text { per L }\end{array}$ & Quercus ilex & $\begin{array}{l}\text { Sorbus } \\
\text { aucuparia }\end{array}$ & $\begin{array}{l}\text { Fagus } \\
\text { sylvatica }\end{array}$ \\
\hline Water (control) & - & $0.777 \mathrm{a}$ & $0.588 \mathrm{a}$ & $0.349 \mathrm{a}$ \\
\hline Maxicrop Original & $10 \mathrm{ml}$ & $0.769 a$ & $0.566 \mathrm{a}$ & $0.339 a$ \\
\hline Maxicrop Original & $20 \mathrm{ml}$ & $0.801 \mathrm{a}$ & $0.572 \mathrm{a}$ & $0.361 \mathrm{a}$ \\
\hline Resistim & $10 \mathrm{ml}$ & $0.779 \mathrm{a}$ & $0.583 a$ & $0.352 \mathrm{a}$ \\
\hline Resistim & $20 \mathrm{ml}$ & $0.761 \mathrm{a}$ & $0.551 \mathrm{a}$ & $0.347 \mathrm{a}$ \\
\hline Bioplex & $10 \mathrm{ml}$ & $0.780 \mathrm{a}$ & $0.557 \mathrm{a}$ & $0.344 \mathrm{a}$ \\
\hline Bioplex & $20 \mathrm{ml}$ & $0.788 \mathrm{a}$ & $0.583 \mathrm{a}$ & $0.327 \mathrm{a}$ \\
\hline Fulcrum CRV & $10 \mathrm{ml}$ & $0.770 \mathrm{a}$ & $0.592 \mathrm{a}$ & $0.350 \mathrm{a}$ \\
\hline Fulcrum CRV & $20 \mathrm{ml}$ & $0.766 \mathrm{a}$ & $0.553 \mathrm{a}$ & $0.341 \mathrm{a}$ \\
\hline Redicrop & $10 \mathrm{ml}$ & $0.758 \mathrm{a}$ & $0.549 \mathrm{a}$ & $0.340 \mathrm{a}$ \\
\hline Redicrop & $20 \mathrm{ml}$ & $0.761 \mathrm{a}$ & $0.571 \mathrm{a}$ & $0.333 \mathrm{a}$ \\
\hline Crop Set & $10 \mathrm{ml}$ & $0.772 \mathrm{a}$ & $0.600 \mathrm{a}$ & $0.360 \mathrm{a}$ \\
\hline Crop Set & $20 \mathrm{ml}$ & $0.762 \mathrm{a}$ & $0.607 a$ & $0.362 \mathrm{a}$ \\
\hline Superthrive & $0.25 \mathrm{ml}$ & $0.790 \mathrm{a}$ & $0.592 \mathrm{a}$ & $0.353 a$ \\
\hline Superthrive & $0.50 \mathrm{ml}$ & $0.789 a$ & $0.560 \mathrm{a}$ & $0.349 \mathrm{a}$ \\
\hline SD & & 0.0126 & 0.0189 & 0.0101 \\
\hline $\mathrm{CV}$ & & 0.0161 & 0.0330 & 0.0286 \\
\hline
\end{tabular}

Note: All values mean of 10 trees; five leaves per tree. Different letters represent significant differences between treatments at the 95\% confidence level. SD = Standard Deviation, CV = Coefficient of Variation. 
Table 3. Lethal salt concentration $\left(\mathrm{SC}_{50}\right)$ required to reduce leaf photochemical efficiency by $50 \%$ based on chlorophyll fluorescence (Fv/Fm) values.

\begin{tabular}{llll}
\hline Treatment & $\begin{array}{l}\text { Concentration } \\
\text { per L }\end{array}$ & $\begin{array}{l}\text { Quercus ilex } \\
\text { SC }_{50}\end{array}$ & $\begin{array}{l}\text { Ilex aquifolium } \\
\text { SC }_{50}\end{array}$ \\
\hline Water (control) & - & $7.7 \% \mathrm{a}$ & $6.7 \% \mathrm{a}$ \\
Maxicrop Original & $10 \mathrm{ml}$ & $7.6 \% \mathrm{a}$ & $6.5 \% \mathrm{a}$ \\
Maxicrop Original & $20 \mathrm{ml}$ & $7.4 \% \mathrm{a}$ & $6.8 \% \mathrm{a}$ \\
Resistim & $10 \mathrm{ml}$ & $7.9 \% \mathrm{a}$ & $6.5 \% \mathrm{a}$ \\
Resistim & $20 \mathrm{ml}$ & $8.0 \% \mathrm{a}$ & $6.6 \% \mathrm{a}$ \\
Bioplex & $10 \mathrm{ml}$ & $7.7 \% \mathrm{a}$ & $6.9 \% \mathrm{a}$ \\
Bioplex & $20 \mathrm{ml}$ & $7.3 \% \mathrm{a}$ & $6.6 \% \mathrm{a}$ \\
Fulcrum CRV & $10 \mathrm{ml}$ & $7.9 \% \mathrm{a}$ & $6.5 \% \mathrm{a}$ \\
Fulcrum CRV & $20 \mathrm{ml}$ & $8.0 \% \mathrm{a}$ & $6.3 \% \mathrm{a}$ \\
Redicrop & $10 \mathrm{ml}$ & $7.4 \% \mathrm{a}$ & $6.6 \% \mathrm{a}$ \\
Redicrop & $20 \mathrm{ml}$ & $7.4 \% \mathrm{a}$ & $6.8 \% \mathrm{a}$ \\
Crop Set & $10 \mathrm{ml}$ & $7.6 \% \mathrm{a}$ & $6.9 \% \mathrm{a}$ \\
Crop Set & $20 \mathrm{ml}$ & $7.2 \% \mathrm{a}$ & $6.9 \% \mathrm{a}$ \\
Superthrive & $0.25 \mathrm{ml}$ & $7.8 \% \mathrm{a}$ & $6.6 \% \mathrm{a}$ \\
Superthrive & $0.50 \mathrm{ml}$ & $7.8 \% \mathrm{a}$ & $6.4 \% \mathrm{a}$ \\
& & & \\
SD & & 0.2499 & 0.1803 \\
CV & & 0.0342 & 0.0267 \\
\hline
\end{tabular}

Note: Results are expressed as the percentage concentration of salt spray required to reach the SC . All values mean of 10 trees; five leaves per tree. Different letters represent significant differences between treatments at the $95 \%$ confidence level. $\mathrm{SD}=$ Standard Deviation, CV $=$ Coefficient of Variation.

\section{DISCUSSION}

Results of this study provide no support for the use of these biostimulants to enhance stress tolerance. In support of these results, a range of biostimulants and humate-based products marketed as aids to reduce transplant stress and enhance tree establishment of balled-and-burlapped red maple (Acer rubrum L. 'Franksred') had little beneficial effects on tree growth and survival (Kelting et al. 1998). Further work investigating the interaction between fertilization, irrigation, and biostimulants on red maple and Washington hawthorn [Crataegus phaenopyrum (Blume) Hare] produced similar conclusions (Kelting et al. 1998). Work by Barnes and Percival (2006) concluded that two biostimulant products that are frequently used in the UK and the United States, when applied at differing concentrations to reduce transplant stress, had few positive effects on growth and vitality of trees at week 8 and 20 after bud break. Indeed, many studies on trees indicate little or no effect of bistimulants upon alleviating stress (Kelting et al. 1997; Thalheimer and Paoli 2001; Ferrini and Nicese 2002; Gilman 2004; Sammons and Struve 2004; Banks and Percival 2012).

Contrary to the research previously noted, Thompson (2004) and Sahain et al. (2007) demonstrate positive growth effects following an application of the biostimulants Plantali (sea algae complex), Lysaplant (membrane effector), and beneficial microorganisms (EM) on a number of tree species, including apple (Malus domestica 'Anna'), Sitka spruce (Picea sitchensis), Scots pine (P. sylvestris), English oak (Quercus robur), ash (Fraxinus excelsior), and birch (Betula pubescens). Thompson (2004) argues that biostimulants appear to work optimally when plants are under environmental stress from poor growing conditions, pathogen attack, or reduced fertilizer inputs. Mancuso et al. (2006) and Roberts and Linder (2010) demonstrated that applications of biostimulants with marine bioactive substances and humectants, respectively, reduced drought stress in containergrown red maple, red oak (Quercus rubra L.), yellow-poplar (Liriodendron tulipifera L.), and grape (Vitis vinifera L.). Mancuso et al. (2006) found that marine bioactive substances applied to Vitis vinifera plants were "very effective in inducing water-stress tolerance, maintaining higher leaf water potential and stomatal conductance" during six days of complete water deprivation.

Previous research highlights specific constraints that must be taken into account for biostimulant treatments to reduce the impact of environmental stress on plants (Fraser and Percival 2003; Richardson et al. 2004; Barnes and Percival 2006). Selection of an appropriate biostimulant can be critical, as effects on growth may vary widely between species, possibly as a result of i) differing active ingredients in the formulation of a product and ii) the concentration applied (Fraser and Percival 2003; Barnes and Percival 2006). In many 
cases, biostimulant substances are poorly defined and highly variable in their active ingredients, mode of action, and species specificity (Corkidi et al. 2004; Barnes and Percival 2006; Roberts and Linder 2010). These traits raise concern among professionals over the use of biostimulants within urban environments (Corkidi et al. 2004; Barnes and Percival 2006; Roberts and Linder 2010). With the influx of biostimulants released into the amenity market, evaluating all of them independently is a time-consuming and labor-intensive process. Consequently, where independent scientific data are not available to support the claims of the manufacturer, use of an unevaluated biostimulant is not recommended. To support manufacturers' claims, it is suggested they should fund independent research (i.e., university grants) as a cost-effective means of evaluating their products prior to release for purchase. Indeed, based on the result of this and other supporting papers, more inexpensive and proven techniques exist to reduce environmental stress in urban landscape conditions, such as the appropriate application of mulches (Chalker-Scott 2007; Percival et al. 2009). Likewise, the environmental harm many of these biostimulant products cause due to the way they are manufactured can be a reason for concern. The harvesting of kelp beds, which are the primary producers of marine intertidal ecosystems, can result in local ecosystem collapse. Concern has been raised regarding the environmental ethics of using products derived from natural sources that have little significant benefit to the end user.

\section{LITERATURE CITED}

Akınc1, S., and D.M. Lösel. 2012. Plant water-stress response mechanisms. Water Stress. Prof. Ismail Md. Mofizur Rahman (Ed.). $<$ www.intechopen.com/books/water-stress/plant-water-stressresponse-mechanisms $>$

Al-Habsi, S., and G.C. Percival. 2006. Sucrose-induced tolerance to and recovery from deicing salt damage in containerized Ilex aquifolium L. and Quercus robur L. Arboriculture \& Urban Forestry 32(6):277-285.

Banks, J.M., and G.C. Percival. 2012. Evaluation of biostimulants to control Guignardia leaf blotch (Guignardia aesculi) of horse chestnut and black spot (Diplocarpon rosae) of roses. Arboriculture \& Urban Forestry 38(6)258-261.

Barnes, S., and G.C. Percival. 2006. Influence of biostimulants and water-retaining polymer root dips on survival and growth of newly transplanted bare-rooted silver birch and rowan. Journal of Environmental Horticulture 24(3):173-179.

Black, P.B. 2012. Is everything bigger in Texas? From the top. Tree News 31:5.
Chalker-Scott, L. 2007. Impact of mulches on landscape plants and the environment - A review. Journal of Environmental Horticulture 25(4):239-249.

Corkidi, L., E.B. Allen, D. Merhaut, M.F. Allen, J. Downer, J. Bohn, and M. Evans. 2004. Assessing the infectivity of commercial mycorrhizal inoculants in plant nursery conditions. Journal of Environmental Horticulture 22(3):149-154.

Cresswell, G.C., and R.G. Weir. 1997. Common nutritional problems and their correction. Plant Nutrient Disorders 5, Ornamental Plants and Shrubs. Butterworth-Heinemann Ltd. Oxford, UK.

Ferrini, E., and F.P. Nicese. 2002. Response of English oak (Quercus robur L.) trees to biostimulant applications in the urban environment. Journal of Arboriculture 28:70-76.

Fraser, G.A., and G. C. Percival. 2003. The influence of biostimulants on growth and vitality of three urban tree species following transplanting. Arboricultural Journal 27(1):43-57.

Gibbs, J.N., and C.A. Palmer. 1994. A survey of damage to roadside trees in London caused by the application of deicing salt during the 1990/91 winter. Arboricultural Journal 18(2):321-343.

Gilman, E.F. 2004. Effects of amendments, soil additives and irrigation on tree survival and growth. Journal of Arboriculture 30(5):301-311.

Glenn, G.M., A.S.N. Reddy, and B.W. Poovaiah. 1988. Effect of calcium on cell wall structure protein phosphorylation and protein profile in senescing apples. Plant and Cell Physiology 29(4):565-572.

Jensen, M., S. Chakir, and G.B. Feige. 1999. Osmotic and atmospheric dehydration effects in the lichens Hypogymnia physodes, Lobaria pulmonaria, and Peltigera aphthosa: An in vivo study of the chlorophyll fluorescence induction. Photosynthetica 37(3):393-404.

Kelting, M., J.R. Harris, J. Fanelli, and B. Appleton. 1998. Humatebased biostimulants affect early post-transplant root growth and sapflow of balled and burlapped red maple. HortScience 33:342-244.

Kelting, M., J.R. Harris, J. Fanelli, B. Appleton, and A. Niemiea. 1997. Humate-based biostimulants do not consistently increase growth of container-grown Turkish hazelnut. Journal of Environmental Horticulture 15(4):197-199.

Levene, H. 1960. Robust tests for equality of variances. In: W.G. Madow and H.B. Mann (Eds.). Contributions to Probability and Statistics. Stanford University Press, Stanford, California, U.S.

Mancuso, S., E. Azzarello, S. Mugnai, and X. Briand. 2006. Marine bioactive substances (ipa extract) improve foliar ion uptake and water stress tolerance in potted Vitis vinifera plants. Advances in Horticultural Science 20(2):156-161.

Marçais B., and N. Bréda. 2006. Role of an opportunistic pathogen in the decline of stressed oak trees. Journal of Ecology 94:1214-1223.

Marschner, H. 2012. Mineral nutrition of plants. Academic Press, London, UK.

Meinander, O., S. Somersalo, T. Holopainen, and R.J. Strasser. 1996. Scots pine after exposure to elevated ozone and carbon dioxide probed by reflectance spectra and chlorophyll a fluorescence transients. Journal of Plant Physiology 148:229-236.

Pachauri, R.K., and A. Reisinger. 2007. Contribution of working groups i, ii, and iii to the fourth assessment report of the intergovernmental panel on climate change. IPCC. Geneva, Switzerland.

Percival, G.C., and C.N. Sheriffs. 2002. Identification of droughttolerant woody perennials using chlorophyll fluorescence. Journal of Arboriculture 28(5):215-223. 
Percival, G.C., and S. Barnes. 2008. Calcium-induced freezing and salinity tolerance in evergreen oak and apple cv. 'Golden Crown'. Arboriculture \& Urban Forestry 34(3):191-199.

Percival, G.C., E. Gklavakis, and K. Noviss. 2009. Influence of pure mulches on survival, growth, and vitality of containerized and field planted trees. Journal of Environmental Horticulture 27(4):200-206

Raese, J.T. 1996. Winter hardiness increased with calcium treatments, Part B. Good Fruit Grower 47(4):41-48.

Richardson, A.D., M. Aikens, G.P. Berlyn, and P. Marshall. 2004. Drought stress and paper birch (Betula papyrifera) seedlings: Effects of an organic biostimulant on plant health and stress tolerance, and detection of stress effects with instrument based non-invasive methods. Journal of Arboriculture 30(1):52-62.

Roberts, B.R., and R.S. Linder. 2010. Humectants as post-plant soil amendments: Effects on the wilting cycle of drought-stressed, container-grown tree seedlings. Arboriculture \& Urban Forestry 36(6):275-280

Roberts, J., N. Jackson, and M. Smith. 2006. Coping with soil contamination. pp. 209-241. In: Tree Roots in the Built Environment. The Stationery Office. Norwich.

Rosenqvist, E., and O. van Kooten. 2003. Chlorophyll fluorescence a general description and nomenclature. In: DeEll and Toivonen. Practical Applications of Chlorophyll Fluorescence in Plant Biology. Boston: Kluwer Academic Publishers 201-242.

Sahain, M.F.M., E.Z.A. El Motty, M.H. El-Shiekh, and L.F. Hagagg. 2007. Effect of some biostimulant on growth and fruiting of anna apple trees in newly reclaimed areas. Research Journal of Agriculture and Biological Science 3(5):422-429.

Sammons, J.D., and D. K. Struve. 2004. Effect of Bioplex on transplant success of non-dormant red oak (Quercus rubra L.). Journal of Environmental Horticulture 22(4):197-202.

Spann, T.M., and H.A. Little. 2011. Applications of a commercial extract of the brown seaweed Ascophyllum nodosum increases drought tolerance in container-grown 'hamlin' sweet orange nursery trees. HortScience 46(4)577-582.

Taiz, L., and E. Zeiger. 1991. Plant physiology. First Edition. Benjamin Cummings. Redwood City, California, U.S.

Thalheimer, M., and N. Paoli. 2001. Effectiveness of various leafapplied biostimulants on productivity and fruit quality of apple. International Symposium on Foliar Nutrition of Perennial Fruit Plants 594. ISHS Acta Horticulturae.

Thompson, B.E. 2004. Five years of Irish trials on biostimulants: The conversion of a skeptic. pp. 72-79. In: L.E. Riley, R.K. Dumroese, and T.D. Landis (Eds.). National proceedings: Forest and Conservation Nursery Associations 2003; USDA Forest Service RMRS-P-33.

Jonathan M. Banks

Bartlett Tree Research Laboratory

John Harborne Building, Whiteknights

University of Reading, Reading

Berkshire, RG6 6AS

jbanks@bartlettuk.com

Glynn C. Percival (corresponding author)

Bartlett Tree Research Laboratory

John Harborne Building, Whiteknights

University of Reading, Reading

Berkshire, RG6 6AS

gpercival@bartlettuk.com
Zusammenfassung. Urbane Umweltbedingungen präsentieren ein Feld von begrenzenden Lebensbedingungen für die Biologie von Bäumen. Zwei Hauptprobleme schließen Auftausalze, ein häufiger Bodenverschmutzer, und Trockenheit ein. Eine mögliche Option zum Umgang mit diesen ökologischen Problemen könnte in der Applikation kommerziell erhältlicher Biostimulantien liegen, da diese Produkte beworben werden als Verbesserung der Pflanzenwiderstandskraft gegenüber stressigen Umweltbedingungen. In Versuchen wurden Containerpflanzen von Immergrüner Eiche (Quercus ilex), Stechpalme (Ilex aquifolium), Vogelbeere (Sorbus aucuparia), und Buche (Fagus sylvatica) verwendet, um die Effektivität von sieben kommerziell erhältlichen Biostimulantien als Komponente gegen Salz und Trockenheit zu bewerten. Die Ergebnisse zeigen, dass keines der getesteten Biostimulantien in dieser Studie irgendeinen signifikanten Schutz gegen Salz oder Trockenheit im Vergleich zur Kontrolle lieferte.

Resumen. Los entornos urbanos presentan una serie de factores ambientales perjudiciales para la biología de los árboles. Dos problemas principales son las sales para deshielo, un contaminante común del suelo, y la sequía. Una posible opción para la gestión de estos trastornos ambientales puede ser a través de la aplicación de bioestimulantes disponibles comercialmente, ya que estos productos son presentados para mejorar la resistencia de la planta al estrés ambiental. Los ensayos utilizaron contenedores con encino (Quercus ilex), acebo (Ilex aquifolium), serbal (Sorbus aucuparia) y haya (Fagus sylvatica) para evaluar la eficacia de siete bioestimulantes disponibles en el mercado como compuestos protectores contra la sal y la sequía. Los resultados concluyen que ninguno de los bioestimulantes evaluados en este estudio proporcionó un grado significativo de protección contra el daño por sal o la sequía, en comparación con los controles tratados con agua. 